\title{
Article \\ Electrodeposition of Indium from an Ionic Liquid Investigated by In Situ Electrochemical XPS
}

\author{
Zhen Liu *, Jun Cheng, Oliver Höfft and Frank Endres *(D)
}

check for updates

Citation: Liu, Z.; Cheng, J.; Höfft, O.; Endres, F. Electrodeposition of Indium from an Ionic Liquid Investigated by In Situ

Electrochemical XPS. Metals 2022, 12, 59. https://doi.org/10.3390/ met12010059

Academic Editor: Bernd Friedrich

Received: 6 December 2021

Accepted: 22 December 2021

Published: 27 December 2021

Publisher's Note: MDPI stays neutral with regard to jurisdictional claims in published maps and institutional affiliations.

Copyright: (c) 2021 by the authors. Licensee MDPI, Basel, Switzerland. This article is an open access article distributed under the terms and conditions of the Creative Commons Attribution (CC BY) license (https:/ / creativecommons.org/licenses/by/ $4.0 /)$.
Institute of Electrochemistry, Clausthal University of Technology, Arnold-Sommerfeld-Strasse 6, 38678 Clausthal-Zellerfeld, Germany; jun.cheng@tu-clausthal.de (J.C.); oliver.hoefft@tu-clausthal.de (O.H.)

* Correspondence: zhen.liu@tu-clausthal.de (Z.L.); frank.endres@tu-clausthal.de (F.E.)

\begin{abstract}
The electrochemical behavior and electrodeposition of indium in an electrolyte composed of $0.1 \mathrm{~mol} / \mathrm{L} \mathrm{InCl}_{3}$ in 1-butyl-1-methylpyrrolidinium bis(trifluoromethylsulfonyl)amide ([Py, $\left.\mathrm{Py}_{1, \mathrm{TFSI}}\right)$ on a gold electrode were investigated. The cyclic voltammogram revealed several reduction and oxidation peaks, indicating a complex electrochemical behavior. In the cathodic regime, with the formation of an In-Au alloy, the reduction of $\operatorname{In}(\mathrm{III})$ to $\operatorname{In}(\mathrm{I})$ and of $\operatorname{In}(\mathrm{I})$ to $\operatorname{In}(0)$ takes place. In situ electrochemical X-ray photoelectron spectroscopy (XPS) was employed to investigate the reduction process by monitoring the oxidation states of the components during the cathodic polarization of $0.1 \mathrm{~mol} / \mathrm{L} \mathrm{InCl}_{3} /\left[\mathrm{Py}_{1,4}\right]$ TFSI on a gold working electrode under ultra-high vacuum (UHV) conditions. The core electron binding energies of the IL components (C 1s, O 1s, F 1s, N 1s, and S 2p) shift almost linearly to more negative values as a function of the applied cell voltage. At $-2.0 \mathrm{~V}$ versus Pt-quasi reference, $\mathrm{In}(\mathrm{I})$ was identified as the intermediate species during the reduction process. In the anodic regime, a strong increase in the pressure in the XPS chamber was recorded at a cell voltage of more than $-0.5 \mathrm{~V}$ versus Pt quasi reference, which indicated, in addition to the oxidation reactions of In species, that the oxidation of $\mathrm{Cl}^{-}$occurs. Ex situ XPS and XRD results revealed the formation of metallic In and of an In-Au alloy.
\end{abstract}

Keywords: ionic liquid; indium; electrodeposition; in situ XPS; In-Au alloy

\section{Introduction}

Indium is of great interest in the semiconductor industry. Indium compounds, such as indium antimonide ( $\mathrm{InSb}$ ), indium phosphide (InP), and copper indium gallium selenide (CIGS), are widely used in light-emitting diodes (LEDs), laser diodes, and photovoltaic devices [1,2]. Indium is produced only as a by-product during the processing of the ores of other metals [3]. Therefore, the development of efficient methods for refining or recycling indium is necessary to meet the growing demand for indium [3].

Electrochemical deposition is an effective technique for refining metals, because of its high deposition rate, simplicity and flexibility, and rather low-cost equipment requirement [4]. Electrodeposition of indium from aqueous electrolytes has been extensively studied $[5,6]$. However, owing to hydrogen embrittlement, a rather low efficiency is achieved and dendritic growth of indium is obtained. Non-aqueous solutions have drawn much attention to the electrodeposition of indium. Monnens et al. reported indium electrodeposition from DMSO, 1,2-dimethoxyethane and poly(ethylene glycol), respectively [7,8]. It was shown that the reduction of $\operatorname{In}(\mathrm{III})$ to both $\operatorname{In}(\mathrm{I})$ and $\operatorname{In}(0)$ occurred and micron- and nano-sized metallic indium were formed. Ionic liquids (ILs) have several advantages as electrolytes for the deposition of metals, such as good conductivity, low vapor pressure, good thermal stability, and a wide electrochemical window [9-11]. The electrodeposition of indium from ionic liquids has also been reported. The electrochemistry of indium in an $\mathrm{InCl}_{3}$ /1-ethyl-3-methylimidazolium chloride/tetrafluoroborate electrolyte on glassy carbon, tungsten, and nickel electrodes was investigated by Yang et al. [12]. The electrochemical behavior of indium in the IL trihexyl(tetradecyl)phosphonium chloride (Cyphos 
IL 101) was reported by Deferm et al. [13]. Our group has also studied the electrodeposition of indium on polycrystalline platinum substrates from 1-butyl-1-methylpyrrolidinium bis(trifluoromethylsulfonyl)amide ([Py $\left.\left.y_{1,4}\right] \mathrm{TFSI}\right)$ containing $0.1 \mathrm{~mol} / \mathrm{L} \mathrm{InCl}_{3}$. Nanocrystalline indium with grain sizes between 100 and $200 \mathrm{~nm}$ was formed in the employed ionic liquid [14].

However, the electrochemical behavior of indium in these organic systems is quite complicated; for example, the cyclic voltammogram of $0.1 \mathrm{~mol} / \mathrm{L} \mathrm{InCl}_{3}$ in $\left.\left[\mathrm{Py}_{1,4}\right] \mathrm{TFSI}\right)$ recorded on a $\mathrm{Pt}$ substrate shows at least five reduction peaks and it is difficult to assign these peaks [14]. These experimental parameters (voltage, current, concentration, and so on) play an important role in synthesizing high-quality indium deposits. Therefore, a fundamental understanding of the speciation of indium and of the electrochemical process is critical. In situ electrochemical X-ray photoelectron spectroscopy (XPS) raises new prospects for the investigation of the electrochemical reactions in a variety of low vapor pressure ionic liquids. The oxidation of $\mathrm{Cu}$ to $\mathrm{Cu}(\mathrm{I})$ and the reduction of $\mathrm{Fe}(\mathrm{III})$ to $\mathrm{Fe}(\mathrm{II})$ in ILs have been monitored using in situ electrochemical-XPS [15]. The electrodeposition of potassium and rubidium has been reported by Compton et al., using in situ XPS [16,17]. We ourselves have studied the formation of anionic gold species by cathodic corrosion of a gold electrode in an ionic liquid electrolyte by in situ XPS [18]. The electrochemical reduction of gallium(III) species in $\left[\mathrm{Py}_{1,4}\right]$ TFSI was also studied under ultra-high vacuum (UHV) conditions by us with in situ XPS. It was shown that low oxidation states of gallium $(\mathrm{Ga}(\mathrm{I})$ or $\mathrm{Ga}(\mathrm{II}))$ were formed and their disproportionation reactions to $\mathrm{Ga}(0)$ and $\mathrm{Ga}(\mathrm{III})$ have been demonstrated [19]. These studies have revealed that in situ XPS can offer a tremendous amount of information on the electrochemical reactions of interest.

Therefore, in the present paper, we employ in situ XPS to monitor the electrochemical reactions of indium in $\left[\mathrm{Py}_{1,4}\right]$ TFSI under UHV. The core electron binding energies of the component were recorded as a function of cell voltage. If the bonding of an element or its oxidation state changes, this also leads to a change in the binding energy of the core electrons. This is denoted as "chemical shift". An oxidation leads to an increase in the binding energy, a reduction to a decrease $[20,21]$. With this, the electrochemical reduction process and the reduced indium species were identified. During cathodic polarization, $\operatorname{In}(\mathrm{I})$ species were identified as the intermediate species during the reduction process. In the cathodic regime, the formation of In-Au alloy and the reduction of In(III) to In(I) and of In(I) to In(0) take place.

\section{Experimental}

The ionic liquid, 1-butyl-1-methylpyrrolidinium bis(trifluoromethylsulfonyl)amide $\left(\left[\mathrm{Py}_{1,4}\right] \mathrm{TFSI}\right)$, was purchased in the highest available quality from Io-Li-Tec $(99 \%$, Heilbronn, Germany) and was used after drying under vacuum at $100{ }^{\circ} \mathrm{C}$ for about one week to achieve a water content of below 2 ppm. $\mathrm{InCl}_{3}$ (99.99\%) was obtained from Sigma-Aldrich. The electrochemical cell used for the deposition of indium in the glove-box was made of Teflon, using a three-electrode setup. Gold on glass was used as a working electrode. Pt-wires were used as reference and counter electrodes, respectively. The electrochemical measurements in the glove-box were carried out at room temperature using a VersaSTAT 3F potentiostat (Princeton Applied Research, Oak Ridge, TN, USA). The obtained deposits were characterized using scanning electron microscopy (SEM) (JSM 7610F, JEOL, Tokyo, Japan) and X-ray diffraction (XRD) (Empyrean, Malvern Panalytical, Malvern, UK).

The in situ electrochemical XPS (homemade) cell was made of Teflon and fixed on an XPS sample holder made from stainless steel. The XPS spectra were recorded at room temperature as a function of applied cell voltage. A volume of $\sim 150 \mu \mathrm{L}$ IL was filled in the cell, which has a diameter of $10 \mathrm{~mm}$ and a depth of $0.5 \mathrm{~mm}$. Platinum wires were used as counter and quasi-reference electrodes, respectively. Au wire spirals with a diameter of $0.2 \mathrm{~mm}$ were used as a working electrode (WE). The WE was allowed to partly float on the surface of the IL, forming a three-phase boundary between the IL, Au, and vacuum. The cell setup can be found in our previous paper $[18,19]$. The WE is connected to the sample 
holder, which is grounded. The counter electrode $(C E)$ is placed at the bottom of the cell and the reference electrode (RE) is placed on the sidewall of the cell. The CE and RE are contacted with springs in the analysis chamber, which are connected to the potentiostat outside of the vacuum.

X-ray photoelectron spectroscopy (XPS) measurements were performed with a SPECS Phoibos 150 hemispherical analyzer (Berlin, Germany) a SPECS XR50 M monochromatic $\mathrm{Al} \mathrm{K} \alpha$ source $(1486.6 \mathrm{eV})$. The XPS detailed spectra were recorded with a constant analyzer pass energy of $20 \mathrm{eV}$. The survey was recorded with a constant analyzer pass energy of $30 \mathrm{eV}$. The cell was placed under high vacuum overnight for degassing and the pressure was below $2 \times 10^{-9}$ mbar.

The electrochemical measurements in combination with in situ XPS were also carried out using a VersaSTAT 3F (Princeton Applied Research) potentiostat. Here, the floating ground mode was used, as the working electrode was grounded.

\section{Results and Discussion}

The electrodeposition of indium on a gold substrate from $0.1 \mathrm{~mol} / \mathrm{L} \mathrm{InCl}_{3} /\left[\mathrm{Py}_{1,4}\right] \mathrm{TFSI}$ was first investigated in the glove box. The cyclic voltammogram $(\mathrm{CV})$ of $0.1 \mathrm{~mol} / \mathrm{L}$ $\mathrm{InCl}_{3}$ in $\left[\mathrm{Py}_{1,4}\right]$ TFSI (black) and of pure $\left[\mathrm{Py}_{1,4}\right]$ TFSI (red) on a gold electrode is shown in Figure 1. In the cathodic regime, the electrochemical window of pure $\left[\mathrm{Py}_{1,4}\right] \mathrm{TFSI}$ is limited by the decomposition of $\left[\mathrm{Py}_{1,4}\right]^{+}$cation at voltages $<-3.0 \mathrm{~V}$. The $\mathrm{CV}$ of $0.1 \mathrm{~mol} / \mathrm{L}$ $\mathrm{InCl}_{3} /\left[\mathrm{Py}_{1,4}\right]$ TFSI shows several cathodic processes, $\mathrm{c} 1-\mathrm{c} 4$. The peak $\mathrm{c} 1$ corresponds to underpotential deposition of indium on Au. The cathodic peak $\mathrm{c} 2$ and its corresponding anodic peak a2 result from alloying of indium with gold. The formation of In-Au alloy can be proved by XRD, as will be shown below. The cathodic peaks, $\mathrm{c} 3$ and c4, are related to the bulk reduction of indium(III) to indium(I) and indium(I) to indium(0). The involvement of indium(I) can be eVidenced by the following in situ XPS results. The reduction process c3 is mainly attributed to the reduction of indium(III) to indium(I). At $-1.5 \mathrm{~V}$ (c3), a thin layer of deposit can be obtained. We assume that the indium(I) species underwent a disproportionation reaction to indium(III) and indium(0). The reduction process c4 is due to bulk deposition of indium, where direct reduction of indium(III) to indium(0) and of indium(I) to indium(0) occur.

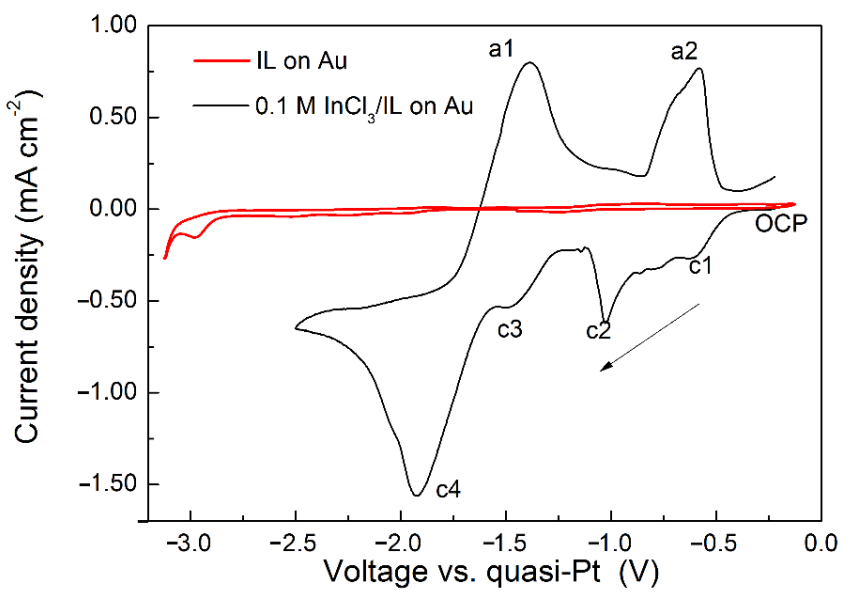

Figure 1. Cyclic voltammogram (CV) of $0.1 \mathrm{~mol} / \mathrm{L} \mathrm{InCl}_{3}$ in $\left[\mathrm{Py}_{1,4}\right]$ TFSI (black) and of pure $\left[\mathrm{Py}_{1,4}\right]$ TFSI (red) on an Au electrode in the glove-box between the open-circuit potential (OCP, $-0.2 \mathrm{~V}$ ) and $-2.5 \mathrm{~V}$ vs. quasi-Pt reference. Scan rate of $10 \mathrm{mV} \mathrm{s}^{-1}$.

The surface morphology of In deposited on $\mathrm{Au}$ from $0.1 \mathrm{M} \mathrm{InCl}_{3} /\left[\mathrm{Py}_{1,4}\right] \mathrm{TFSI}$ after potentiostatic polarization at $-2.2 \mathrm{~V}$ for $2 \mathrm{~h}$ is shown in Figure 2. Dense and compact indium structures were obtained. The EDX profile in the inset of Figure $2 \mathrm{a}$ revealed the deposition of pure metallic indium. 

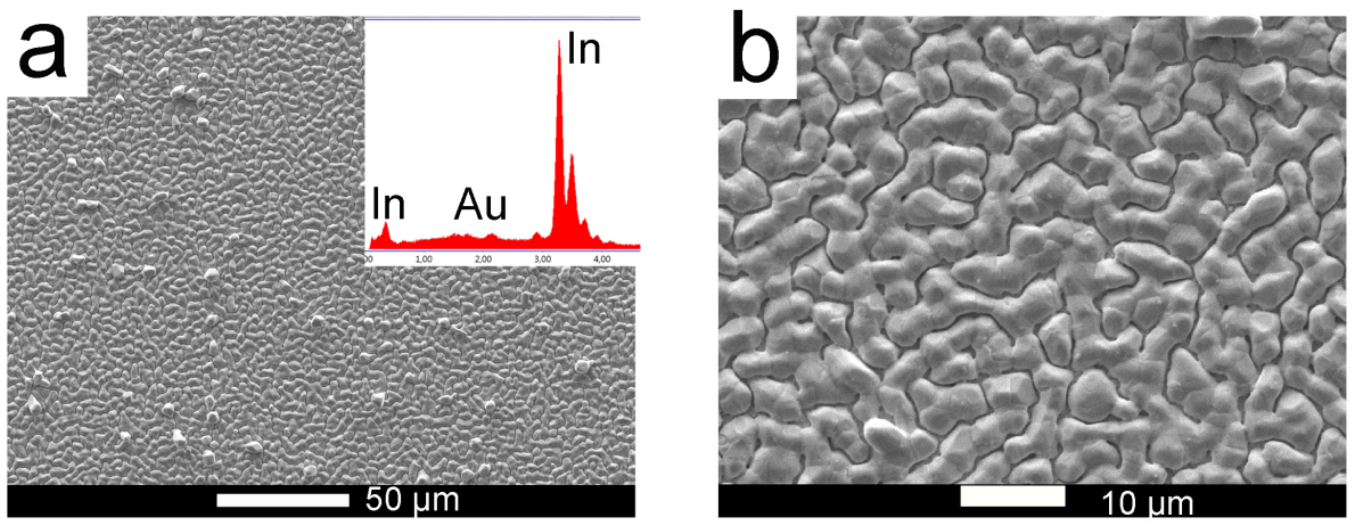

Figure 2. Scanning electron microscopy (SEM) images of indium deposits at low (a) and high (b) magnifications obtained after electrodeposition at $-2.2 \mathrm{~V}$ for $2 \mathrm{~h}$.

The XRD pattern of indium deposits obtained at $-2.2 \mathrm{~V}$ for $2 \mathrm{~h}$ is shown in Figure 3 . The characteristic peaks of indium (blue), of AuIn 2 alloy (green), and of the Au substrate are depicted. The asterisk at $\sim 35^{\circ}$ in Figure 3 is from the gold substrate. XRD reveals clear diffraction peaks for $\operatorname{In}(011), \operatorname{In}(002), \operatorname{In}(110)$, and $\operatorname{In}(112)$ that are consistent with crystalline indium [22]. The particle size calculated by XRD using Scherrer's equation is $\sim 40 \mathrm{~nm}$. The formation of AuIn 2 alloy was eVidenced by $\mathrm{AuIn}_{2}(111)$ at 23.6 ${ }^{\circ}, \mathrm{AuIn}_{2}(022)$ at $39.1^{\circ}$, and $\mathrm{AuIn}_{2}(224)$ at $70.8^{\circ}$ (COD: 96-900-9002).

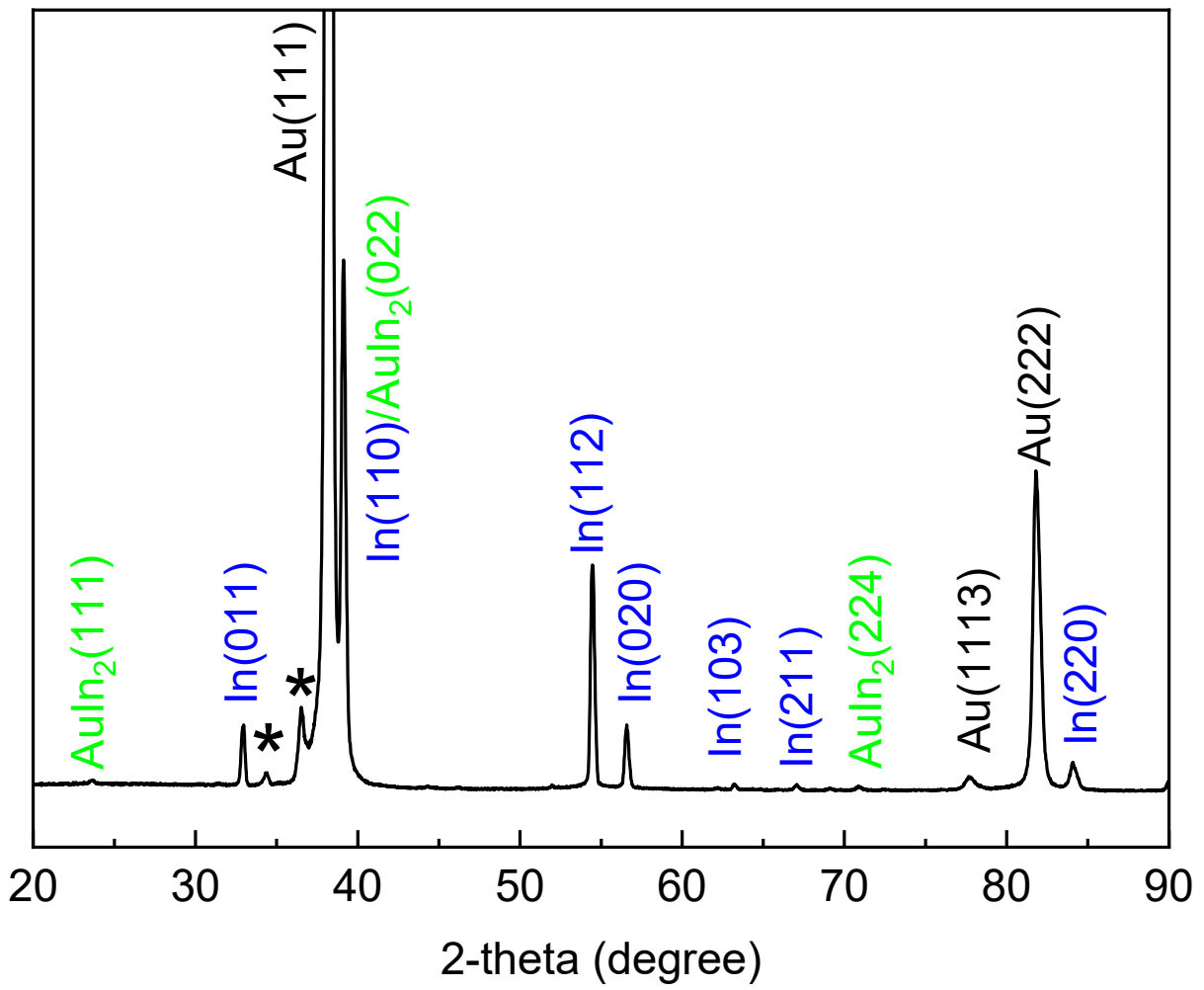

Figure 3. X-ray diffraction (XRD) of indium deposit on $\mathrm{Au}$ substrate from $0.1 \mathrm{~mol} / \mathrm{L} \mathrm{InCl}_{3}$ in $\left[\mathrm{Py}_{1,4}\right]$ TFSI.

In the following experiments, the electrochemical behavior of indium(III) in [Py $\left.\mathrm{P}_{1,4}\right] \mathrm{TFSI}$ was studied in UHV with a pressure of $2 \times 10^{-9}$ mbar inside of the XPS chamber using a three-electrode setup. The binding energies of the components as a function of potential were also monitored. The CV in UHV (Figure S1 in Supplementary Materials) shows a 
similar behavior to that in Figure 1. We have to mention that, in UHV, a strong increase in the pressure from $2 \times 10^{-9}$ mbar to $6 \times 10^{-8}$ mbar was observed in the reverse anodic scan at $\sim-0.5 \mathrm{~V}$. This result also suggests that the oxidation of $\mathrm{Cl}^{-}$occurs at a2. The XPS survey spectrum of $0.1 \mathrm{~mol} / \mathrm{L} \mathrm{InCl}_{3}$ in $\left[\mathrm{Py}_{1,4}\right] \mathrm{TFSI}$ on an Au electrode in the XPS-electrochemistry cell at OCP is shown in Figure 4. The spectrum contains the information from the IL (C 1s, $\mathrm{O} 1 \mathrm{~s}, \mathrm{~F} 1 \mathrm{~s}, \mathrm{~N} 1 \mathrm{~s}$, and S 2p), from $\mathrm{InCl}_{3}$ (In $3 \mathrm{~d}$ and $\mathrm{Cl} 2 \mathrm{p}$ ), and from the Au substrate (Au 4f).

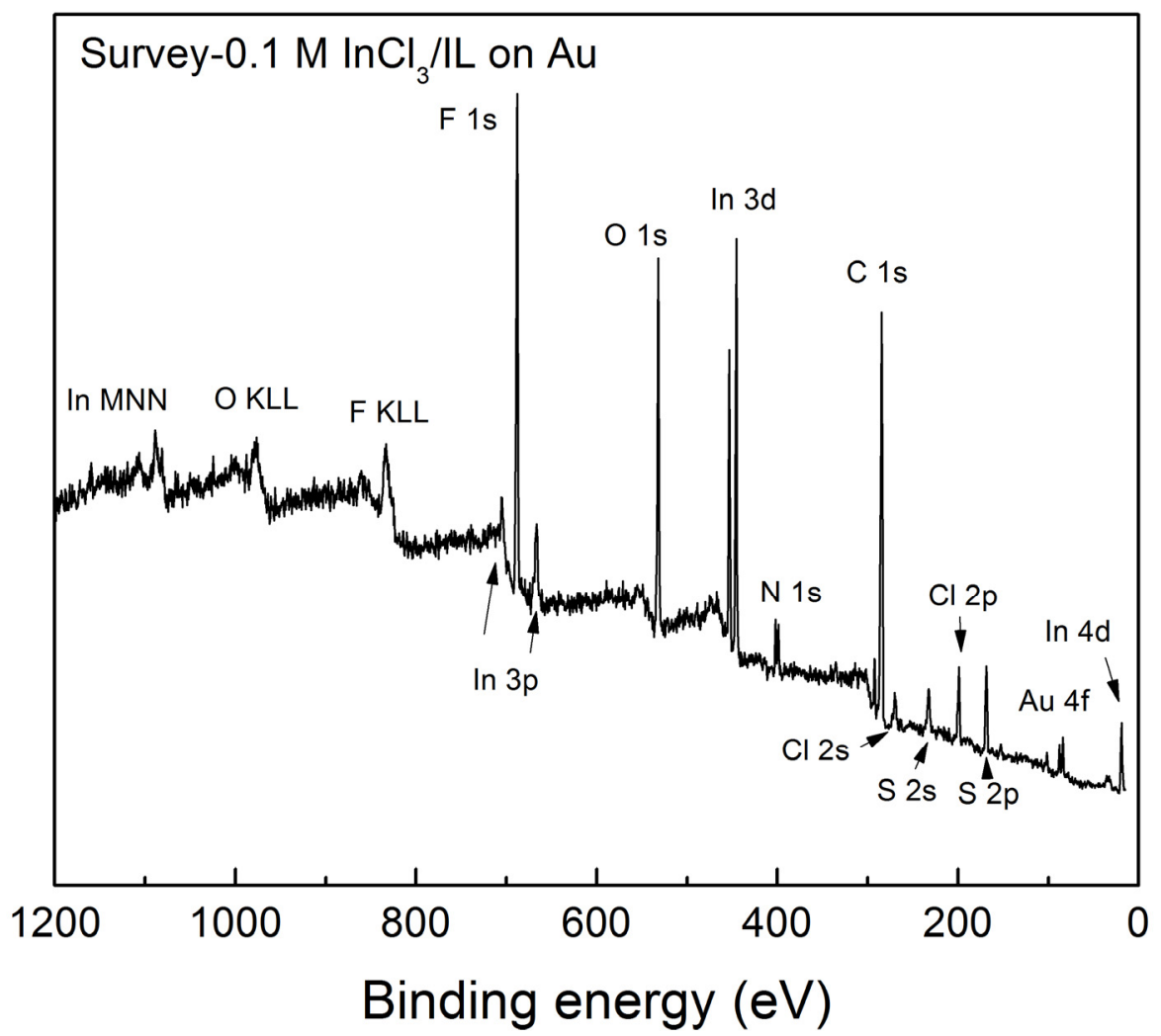

Figure 4. X-ray photoelectron spectroscopy (XPS) survey spectrum of $0.1 \mathrm{~mol} / \mathrm{L} \mathrm{InCl}_{3}$ in $\left[\mathrm{Py}_{1,4}\right] \mathrm{TFSI}$ in the cell setup.

Detailed XPS spectra are shown in Figure 5. One F 1s peak, one O 1s peak, and one $\mathrm{S} 2 \mathrm{p}(2 \mathrm{p} 3 / 2$ and 2p1/2) peak are observed at $688.3 \mathrm{eV}, 532.0 \mathrm{eV}$, and $168.3 \mathrm{eV}$, respectively, which originate from the $\mathrm{TFSI}^{-}$anion. Two $\mathrm{N}$ 1s peaks are observed, which are attributed to $\mathrm{N}_{\text {cation }}(402.0 \mathrm{eV})$ and $\mathrm{N}_{\text {anion }}(398.8 \mathrm{eV})$ of the IL. In the $\mathrm{C} 1 \mathrm{~s}$ spectrum, two peaks are visible, the one centered at $284.5 \mathrm{eV}$ with a shoulder at $287 \mathrm{eV}$ (which belongs to the $\mathrm{C}$ atoms bonded to the nitrogen atom in the pyrrolidinium ring) is due to the $\left[\mathrm{Py}_{1,4}\right]$ cations and the one at $292.2 \mathrm{eV}$ is due to TFSI ${ }^{-}$anions of the $-\mathrm{CF}_{3}$ group. Two In $3 \mathrm{~d}$ peaks (In $3 \mathrm{~d} 5 / 2$ and $3 \mathrm{~d} 3 / 2$ ) are found at $445.5 \mathrm{eV}$ and $453.1 \mathrm{eV}$. The splitting is $7.6 \mathrm{eV}$, which is typical for In 3d. Cl 2p (2p3/2) is observed at $199.0 \mathrm{eV}$ with the $\mathrm{Cl} 2 \mathrm{p} 1 / 2$ shoulder at $200.6 \mathrm{eV}$. The two components of the $\mathrm{Au} 4 \mathrm{f}$ peak ( $\mathrm{Au} 4 \mathrm{f7} / 2$ and $\mathrm{Au} 4 \mathrm{f5} / 2$ ) are found at $84.0 \mathrm{eV}$ and $87.7 \mathrm{eV}$, respectively. These assignments are consistent with previous results [23-27].

Subsequently, a voltage was applied to the cell and the binding energies (BEs) of these orbitals were monitored by XPS. The in situ electrochemical XPS detail spectra of the components as a function of cell voltage are shown in Figure 6. The applied voltage was changed from the OCP $(-0.2 \mathrm{~V})$ to $-2.5 \mathrm{~V}$ in steps of $-0.5 \mathrm{~V}$. In the investigated voltage regimes, both the XPS spectra of the IL, of indium species, and of the Au substrate can be observed, which indicate the X-rays are focused on the three-phase boundary, i.e., vacuum, IL electrolyte, and gold substrate. The BEs of the $\mathrm{Au} 4 \mathrm{f}$ peaks at $84.0 \mathrm{eV}$ and $87.7 \mathrm{eV}$ did not shift when the voltage was applied because the working electrode was grounded. However, the intensity of the Au $4 \mathrm{f}$ peaks reduced, probably because of the electrowetting 
of the IL at more negative potentials. The BEs of the orbitals of the IL components (F 1s, $\mathrm{O} 1 \mathrm{~s}, \mathrm{~N}$ 1s, C 1s, and S 2p) shift to higher BEs as the electrode potential shifts to more negative values. However, they have similar peak intensities. Nevertheless, for the $C 1 \mathrm{~s}$ and $\mathrm{O} 1 \mathrm{~s}$ spectra with increasing potential, additional peaks were observed at $284.8 \mathrm{eV}$ and $532.2 \mathrm{eV}$, respectively, and they are independent of the applied voltage. It is assumed that some species are adsorbed on the gold substrate. Obvious changes were observed for the In $3 \mathrm{~d}$ and $\mathrm{Cl} 2 \mathrm{p}$ spectra. Their intensities were reduced as the voltage shifted to more negative values. In addition, additional peaks are observed at lower BEs than that of bulk components at potentials more negative than $-2.0 \mathrm{~V}$. Deconvoluted spectra and details are shown in Figure 6.
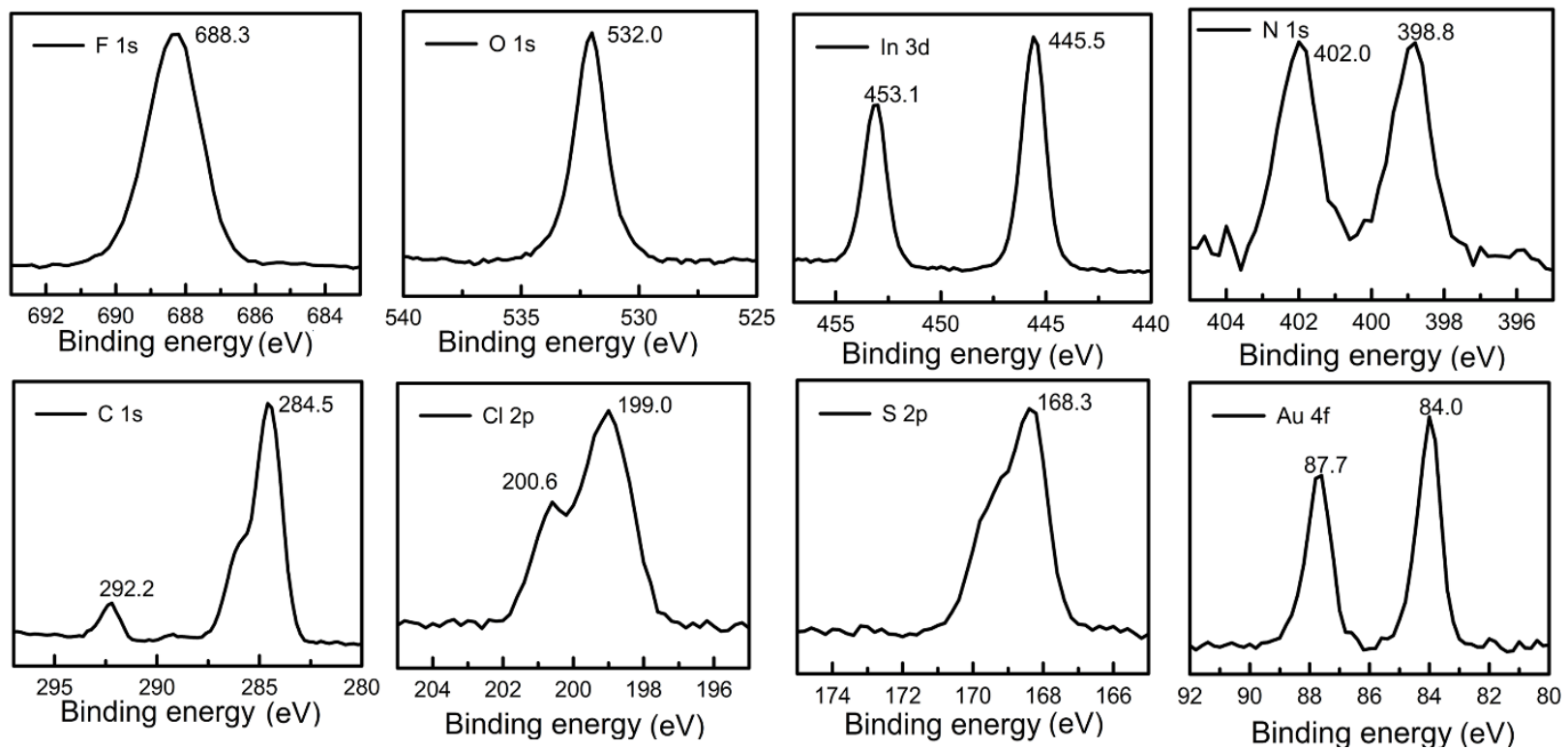

Figure 5. XPS detailed spectra of $0.1 \mathrm{~mol} / \mathrm{L} \mathrm{InCl}_{3}$ in $\left[\mathrm{Py}_{1,4}\right] \mathrm{TFSI}$ in the cell setup.
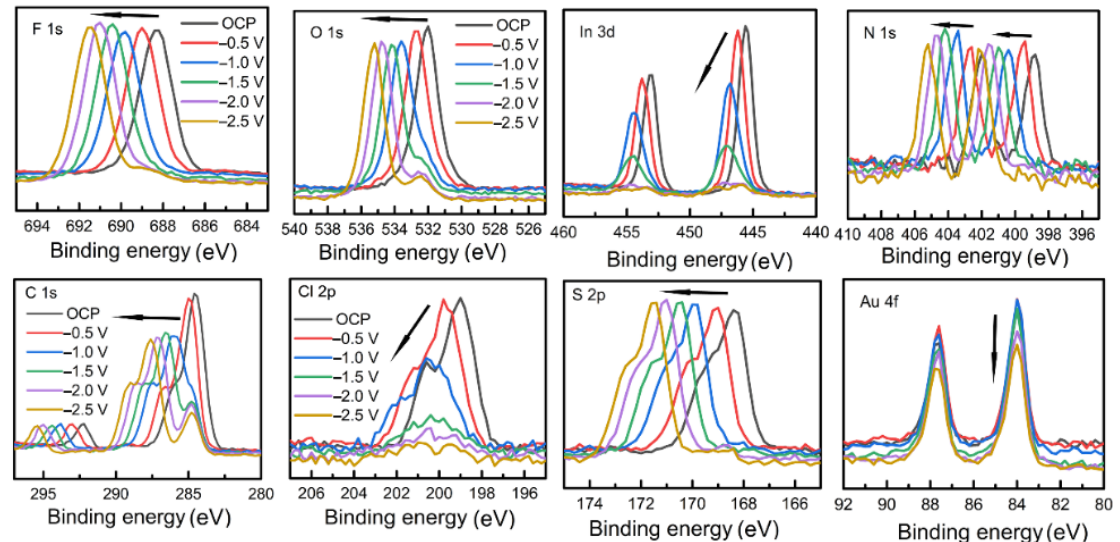

Figure 6. In situ XPS detail spectra of $\mathrm{F} 1 \mathrm{~s}, \mathrm{O}$ 1s, In 3d, N 1s, C 1s, Cl 2p, S 2p, and Au 4f core-level of $0.1 \mathrm{~mol} / \mathrm{L} \mathrm{InCl}_{3}$ in $\left[\mathrm{Py}_{1,4}\right]$ TFSI at different potentials from OCP $(-0.2 \mathrm{~V})$ to $-2.5 \mathrm{~V}$.

The BEs of the above shown orbitals as a function of the electrode potential are plotted in Figure 7. The BE of both $\mathrm{Au} 4 \mathrm{f}$ peaks is independent of the electrode potential. The IL components showed roughly a $-1.0 \mathrm{eV} / \mathrm{V}$ shift in the $\mathrm{BE}$ as the cell voltage changed from $-0.5 \mathrm{~V}$ to $-2.5 \mathrm{~V}$, which suggests that the components in the bulk electrolyte experience the full potential drop. However, it seems that, at OCP, the BEs of the IL associated orbitals are located at low values, possibly because of a charging effect of indium species at the surface.

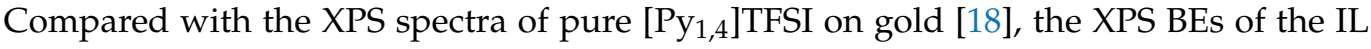


associated orbitals with indium salts show lower BEs of $\sim-0.7 \mathrm{eV}$, that is, for example, $\mathrm{F} 1 \mathrm{~s}$ is found at $689.0 \mathrm{eV}$ for the IL on $\mathrm{Au}$, while it is found at $688.3 \mathrm{eV}$ for the IL with indium salts on $\mathrm{Au}$. Interestingly, the In $3 \mathrm{~d}$ and $\mathrm{Cl} 2 \mathrm{p}$ shift differently from that of the other orbitals as a function of cell voltage. Between $-1.0 \mathrm{~V}$ and $-2.0 \mathrm{~V}$, the curve shows a $\sim 0.5 \mathrm{eV} / \mathrm{V}$ slope. This indicates that the indium species are reduced.

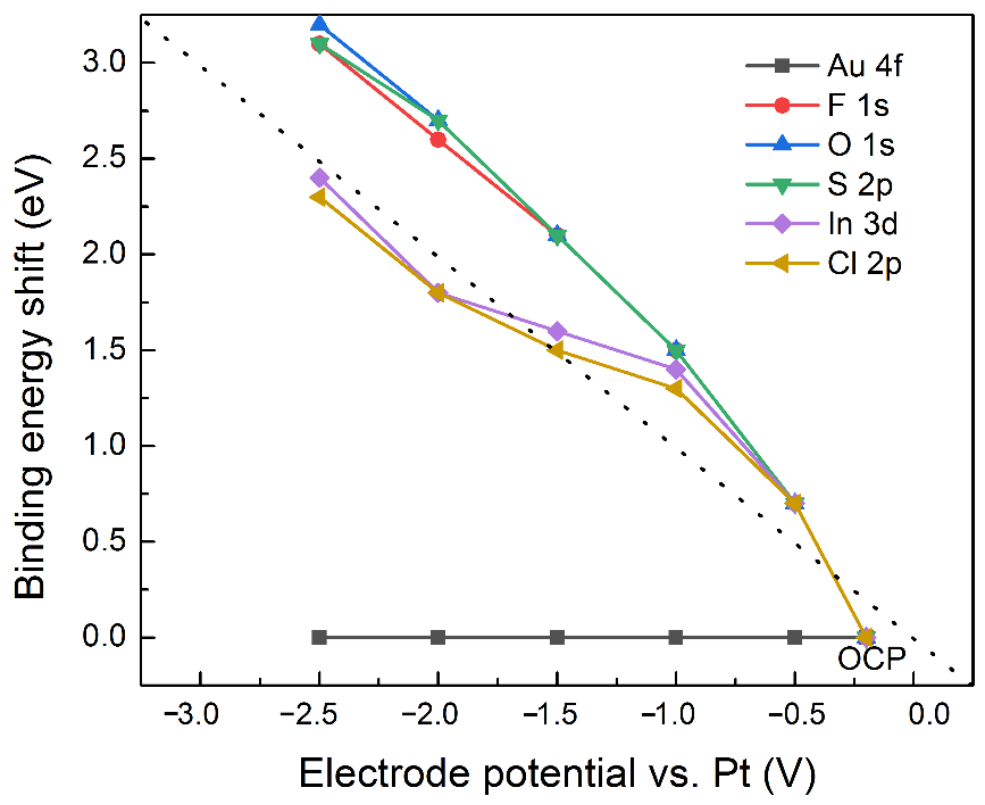

Figure 7. The plot of binding energy shifts of the components and the applied voltage.

The deconvolution of the In $3 \mathrm{~d}$ XPS spectra at $-2.0 \mathrm{~V}$ and at $-2.5 \mathrm{~V}$ is shown in Figure 8 . At $-2.0 \mathrm{~V}$, the spectrum is deconvoluted into three couples. The couple (green peaks) at $447.2 \mathrm{eV}$ and $454.7 \mathrm{eV}$ is attributed to $\operatorname{In}(\mathrm{III}) 3 \mathrm{~d} 5 / 2$ and $\mathrm{In}$ (III) $3 \mathrm{~d} 3 / 2$ in the bulk, respectively. The couple (cyan peaks) at $445.8 \mathrm{eV}$ and $453.2 \mathrm{eV}$ is due to electrochemical reduced $\operatorname{In}(\mathrm{I})$, which is adsorbed on the gold surface. The couple (red peaks) is assigned to metallic indium, which is found at $444.2 \mathrm{eV}$ and $451.7 \mathrm{eV}$. When the potential shifts to $-2.5 \mathrm{~V}$, the In spectrum can also be deconvoluted into three couples. The bulk In(III) couple shifts to $447.9 \mathrm{eV}$ and $455.3 \mathrm{eV}$ (green curves). The adsorbed $\mathrm{In}(\mathrm{I})$ couple (cyan curves) almost do not shift their positions. In addition, the intensity of In(III) decreased and the intensity of $\operatorname{In}(\mathrm{I})$ increased when the voltage changed from $-2.0 \mathrm{~V}$ to $-2.5 \mathrm{~V}$. The results suggest the reduction of $\operatorname{In}(\mathrm{III})$ to $\mathrm{In}(\mathrm{I})$. At $-2.5 \mathrm{~V}$, the BEs of metallic indium are found at 444.0 and $451.5 \mathrm{eV}$. We attribute the formation of metallic indium at these potentials to the electrodeposition process and the disproportionation reaction of $\operatorname{In}(\mathrm{I})$ to $\operatorname{In}(\mathrm{III})$ and $\operatorname{In}(0)$.

After electrodeposition, the in situ electrochemical cell was taken out from the XPS chamber and washed with acetone to remove the IL. The whole process took less than $10 \mathrm{~s}$, in order to reduce the oxidation process. The chemical composition of the deposit was subsequently analyzed by ex situ XPS. Figure 9 represents the XPS detailed spectra of In $3 \mathrm{~d}, \mathrm{Au} 4 \mathrm{f}, \mathrm{O} 1 \mathrm{~s}$, and $\mathrm{Cl} 2 \mathrm{p}$ of the In deposits. In the In $3 \mathrm{~d}$ regime, the peaks at $444.1 \mathrm{eV}$ and $451.6 \mathrm{eV}$ are assigned to metallic indium and the peaks at $446.1 \mathrm{eV}$ and $453.5 \mathrm{eV}$ are attributed to indium oxide or adsorbed $\mathrm{InCl}_{3}$. The $\mathrm{Au} 4 \mathrm{f}$ peaks at $84.2 \mathrm{eV}$ and $87.9 \mathrm{eV}$, which is $+0.2 \mathrm{eV}$ higher than that of metallic $\mathrm{Au}$, are attributed to the formation Au-In alloy or oxidized alloy products [28]. 

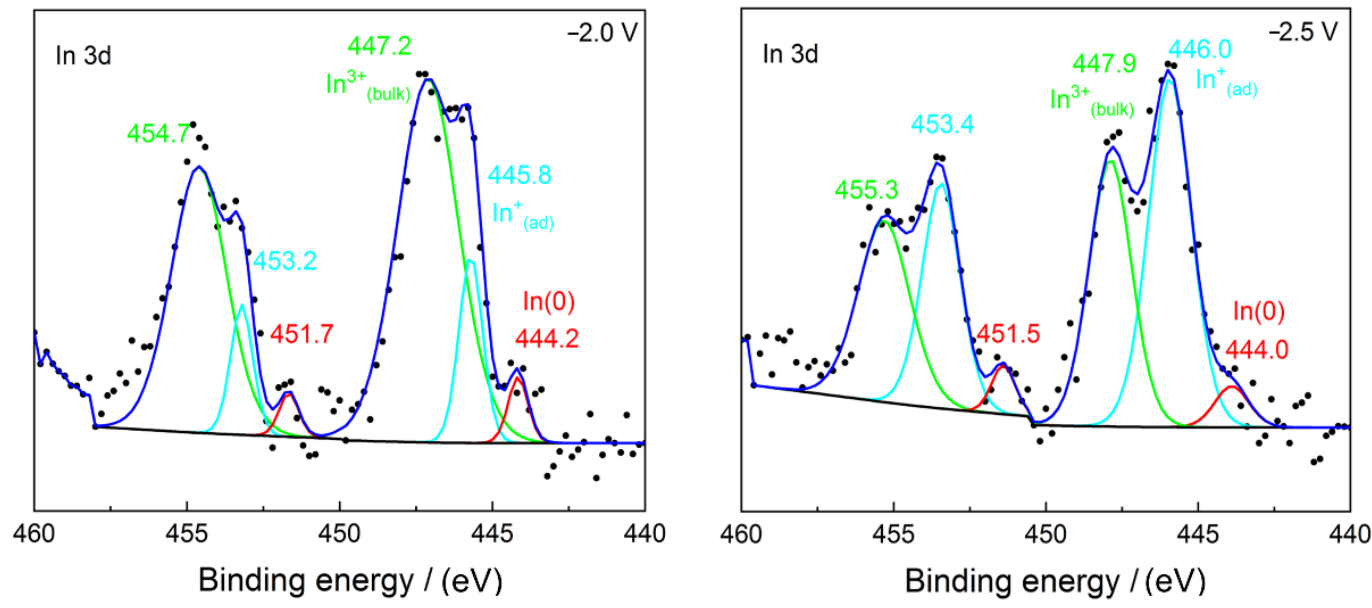

Figure 8. Deconvolution of the in situ XPS In $3 \mathrm{~d}$ spectra at $-2.0 \mathrm{~V}$ and at $-2.5 \mathrm{~V}$.
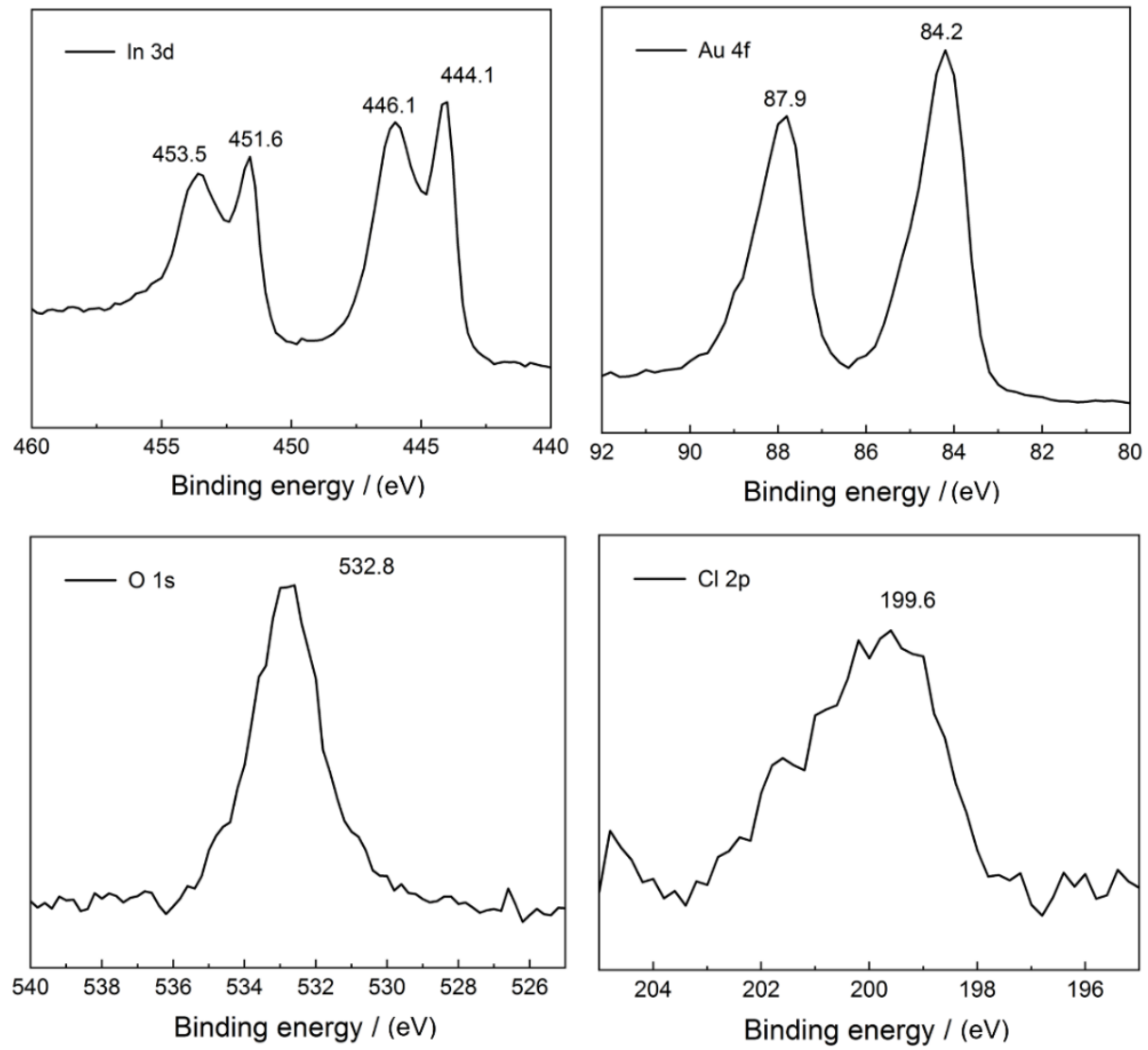

Figure 9. Ex situ XPS spectra of In $3 \mathrm{~d}, \mathrm{Au} 4 \mathrm{f}, \mathrm{O} 1 \mathrm{~s}$, and $\mathrm{Cl} 2 \mathrm{p}$ of the In deposits after washing with acetone.

\section{Conclusions}

A fundamental understanding of the electrochemical deposition process of indium in IL is significant for obtaining high-quality indium deposits. In this paper, we have investigated the electrochemical behavior and electrodeposition of indium on a gold substrate from $0.1 \mathrm{~mol} / \mathrm{L} \mathrm{InCl}_{3}$ in $\left[\mathrm{Py}_{1,4}\right]$ TFSI electrolyte using in situ electrochemical XPS. The CV shows that the electrochemical reduction process is quite complicated and several processes are involved, including the formation of Au-In alloy and reduction of In(III) to $\operatorname{In}(\mathrm{I})$ and $\operatorname{In}(\mathrm{I})$ to $\operatorname{In}(0)$. We confirmed by XRD the formation of $\mathrm{AuIn}_{2}$ alloy. In situ XPS results indicate that $\operatorname{In}(\mathrm{I})$ species are formed during the electrochemical reduction of $\operatorname{In}(\mathrm{III})$. 
In(I) species underwent disproportionation reaction to $\operatorname{In}(\mathrm{III})$ and $\operatorname{In}(0)$. At $-2.5 \mathrm{~V}$, more In(I) species are formed at the gold surface than that at $-2.0 \mathrm{~V}$. Compact and dense indium deposits can be obtained by electrodeposition at -2.2 V. Ex situ XPS and XRD analysis show that the deposit contains metallic In and Au-In alloy.

Supplementary Materials: The following supporting information can be downloaded at: https: //www.mdpi.com/article/10.3390/met12010059/s1, Figure S1: CV of $0.1 \mathrm{~mol} / \mathrm{L} \mathrm{InCl3} \mathrm{in} \mathrm{[Py1,4]TFSI}$ under UHV on an Au electrode between $-0.5 \mathrm{~V}$ and $-2.5 \mathrm{~V}$ vs. quasi-Pt reference. Scan rate of $10 \mathrm{mV} \mathrm{s}^{-1}$.

Author Contributions: Conceptualization, Z.L. and F.E.; methodology, Z.L., J.C. and F.E.; investigation, Z.L. and J.C.; data curation, Z.L. and J.C.; writing-original draft preparation, Z.L, J.C., O.H. and F.E.; writing-review and editing, Z.L., O.H. and F.E.; supervision, F.E. All authors have read and agreed to the published version of the manuscript.

Funding: We would like to thank Deutsche Forschungsgemeinschaft (DFG) (BO 4290/1-2) for financial support.

Institutional Review Board Statement: Not applicable.

Informed Consent Statement: Not applicable.

Data Availability Statement: Data presented in this article are available at request from the corresponding author.

Acknowledgments: The authors are grateful to S. Löffelholz for doing the scanning electron microscopy measurements.

Conflicts of Interest: The authors declare no conflict of interest.

\section{References}

1. Bhattacharya, R.N. CIGS-Based Solar Cells Prepared from Electrodeposited Stacked Cu/In/Ga Layers. Sol. Energy Mater. Sol. Cells 2013, 113, 96-99. [CrossRef]

2. Vaillon, R.; Pérez, J.-P.; Lucchesi, C.; Cakiroglu, D.; Chapuis, P.-O.; Taliercio, T.; Tournié, E. Micron-Sized Liquid Nitrogen-Cooled Indium Antimonide Photovoltaic Cell for near-Field Thermophotovoltaics. Opt. Express 2019, 27, A11-A24. [CrossRef]

3. Alfantazi, A.M.; Moskalyk, R.R. Processing of Indium: A Review. Miner. Eng. 2003, 16, 687-694. [CrossRef]

4. Dharmadasa, I.M.; Haigh, J. Strengths and Advantages of Electrodeposition as a Semiconductor Growth Technique for Applications in Macroelectronic Devices. J. Electrochem. Soc. 2006, 153, G47-G52. [CrossRef]

5. Piercy, R.; Hampson, N.A. The Electrochemistry of Indium. J. Appl. Electrochem. 1975, 5, 1-15. [CrossRef]

6. Walsh, F.C.; Gabe, D.R. The Electrodeposition of Indium. Surf. Technol. 1979, 8, 87-99. [CrossRef]

7. Monnens, W.; Deferm, C.; Binnemans, K.; Fransaer, J. Indium Electrodeposition from Indium (III) Methanesulfonate in DMSO. Phys. Chem. Chem. Phys. 2020, 22, 24526-24534. [CrossRef] [PubMed]

8. Monnens, W.; Deferm, C.; Sniekers, J.; Fransaer, J.; Binnemans, K. Electrodeposition of Indium from Non-Aqueous Electrolytes. Chem. Commun. 2019, 55, 4789-4792. [CrossRef]

9. Abbott, A.P.; McKenzie, K.J. Application of Ionic Liquids to the Electrodeposition of Metals. Phys. Chem. Chem. Phys. 2006, 8, 4265-4279. [CrossRef]

10. Liu, Z.; El Abedin, S.Z.; Endres, F. Electrodeposition of Zinc Films from Ionic Liquids and Ionic Liquid/Water Mixtures. Electrochim. Acta 2013, 89, 635-643. [CrossRef]

11. Liu, Z.; Cui, T.; Pulletikurthi, G.; Lahiri, A.; Carstens, T.; Olschewski, M.; Endres, F. Dendrite-Free Nanocrystalline Zinc Electrodeposition from an Ionic Liquid Containing Nickel Triflate for Rechargeable Zn-Based Batteries. Angew. Chem. Int. Ed. 2016, 55, 2889-2893. [CrossRef] [PubMed]

12. Yang, M.-H.; Sun, I.-W. Electrochemical Study of Indium in a Water-Stable 1-Ethyl-3-Methylimidazolium Chloride/Tetrafluoroborate Room Temperature Ionic Liquid. J. Chin. Chem. Soc. 2004, 51, 253-260. [CrossRef]

13. Deferm, C.; Malaquias, J.C.; Onghena, B.; Banerjee, D.; Luyten, J.; Oosterhof, H.; Fransaer, J.; Binnemans, K. Electrodeposition of Indium from the Ionic Liquid Trihexyl (Tetradecyl) Phosphonium Chloride. Green Chem. 2019, 21, 1517-1530. [CrossRef]

14. El Abedin, S.Z.; Saad, A.Y.; Farag, H.K.; Borisenko, N.; Liu, Q.X.; Endres, F. Electrodeposition of Selenium, Indium and Copper in an Air- and Water-Stable Ionic Liquid at Variable Temperatures. Electrochim. Acta 2007, 52, 2746-2754. [CrossRef]

15. Taylor, A.W.; Qiu, F.; Villar-Garcia, I.J.; Licence, P. Spectroelectrochemistry at Ultrahigh Vacuum: In Situ Monitoring of Electrochemically Generated Species by X-ray Photoelectron Spectroscopy. Chem. Commun. 2009, 39, 5817-5819. [CrossRef]

16. Wibowo, R.; Aldous, L.; Jacobs, R.M.J.; Manan, N.S.A.; Compton, R.G. Monitoring Potassium Metal Electrodeposition from an Ionic Liquid Using in Situ Electrochemical-X-ray Photoelectron Spectroscopy. Chem. Phys. Lett. 2011, 509, 72-76. [CrossRef] 
17. Wibowo, R.; Aldous, L.; Jacobs, R.M.J.; Manan, N.S.A.; Compton, R.G. In Situ Electrochemical-X-ray Photoelectron Spectroscopy: Rubidium Metal Deposition from an Ionic Liquid in Competition with Solvent Breakdown. Chem. Phys. Lett. 2011, 517, 103-107. [CrossRef]

18. Liu, Z.; Höfft, O.; Gödde, A.S.; Endres, F. In Situ Electrochemical XPS Monitoring of the Formation of Anionic Gold Species by Cathodic Corrosion of a Gold Electrode in an Ionic Liquid. J. Phys. Chem. C 2021, 125, 26793-26800. [CrossRef]

19. Liu, Z.; Höfft, O.; Endres, F. Disproportionation Reaction of Gallium During Electrodeposition from an Ionic Liquid, Monitored by in Situ Electrochemical XPS. J. Phys. Chem. C 2021, 125, 24589-24595. [CrossRef]

20. Egelhoff, W.F., Jr. Core-level binding-energy shifts at surfaces and in solids. Surf. Sci. Rep. 1987, 6, 253-415. [CrossRef]

21. Barr, T.L. Advances in the Application of X-Ray Photoelectron Spectroscopy (ESCA) Part I. Foundation and Established Methods. Crit. Rev. Anal. Chem. 1991, 22, 567-635. [CrossRef]

22. Choi, Y.I.; Kim, S.K.; Lee, S.W.; Sohn, Y. Metallic Indium Spheres by the Anaerobic Ethanol Oxidation of Indium Oxide. J. Alloys Compd. 2016, 687, 611-615. [CrossRef]

23. Buchner, F.; Kim, J.; Adler, C.; Bozorgchenani, M.; Bansmann, J.; Behm, R.J. Intercalation and Deintercalation of Lithium at the Ionic Liquid-Graphite (0001) Interface. J. Phys. Chem. Lett. 2017, 8, 5804-5809. [CrossRef]

24. Olschewski, M.; Gustus, R.; Marschewski, M.; Höfft, O.; Endres, F. Spectroscopic Characterization of the Interaction of Lithium with Thin Films of the Ionic Liquid 1-Octyl-3-Methylimidazolium Bis (Trifluoromethylsulfonyl)Amide. Phys. Chem. Chem. Phys. 2014, 16, 25969-25977. [CrossRef]

25. Olschewski, M.; Gustus, R.; Höfft, O.; Lahiri, A.; Endres, F. Monochromatic X-ray Photoelectron Spectroscopy Study of Three Different Ionic Liquids in Interaction with Lithium-Decorated Copper Surfaces. J. Phys. Chem. C 2017, 121, 2675-2682. [CrossRef]

26. Detweiler, Z.M.; Wulfsberg, S.M.; Frith, M.G.; Bocarsly, A.B.; Bernasek, S.L. The Oxidation and Surface Speciation of Indium and Indium Oxides Exposed to Atmospheric Oxidants. Surf. Sci. 2016, 648, 188-195. [CrossRef]

27. Sahoo, S.R.; Ke, S.-C. Spin-Orbit Coupling Effects in Au 4f Core-Level Electronic Structures in Supported Low-Dimensional Gold Nanoparticles. Nanomaterials 2021, 11, 554. [CrossRef]

28. Sutter, E.A.; Tong, X.; Jungjohann, K.; Sutter, P.W. Oxidation of Nanoscale Au-In Alloy Particles as a Possible Route toward Stable Au-Based Catalysts. Proc. Natl. Acad. Sci. USA 2013, 110, 10519-10524. [CrossRef] [PubMed] 